\title{
STRONG BUT NOT UNBEATABLE: TWO CASES OF HEALED SEVERE SKULL TRAUMA IN MALES BURIED IN MEDIEVAL MASS GRAVES (KUTNÁ HORA-SEDLEC, CZECH REPUBLIC)
}

\begin{abstract}
This paper presents two cases of healed skull trauma recovered from medieval mass burial sites in Kutná Hora-Sedlec (Kutná Hora District/CZ). These recently unearthed burial pits are historically and contextually associated with two key catastrophes: (1) a famine in the early $14^{\text {th }}$ century; and (2) the Black Death in the mid-14 $4^{\text {th }}$ century. The first skull presents evidence of survival from severe cranial injury with highly probable surgical intervention. The second one presents evidence of successful skull surgery, confirming the practice of trepanation performed by a skilled specialist in a given region at a given time in history. Although both individuals had been robust enough to withstand the pain and strain of the treatment, indicating considerable resilience to survive the skull trauma, they succumbed to mass infection or famine that killed a large number of inhabitants of this prominent medieval mining region.
\end{abstract}

Keywords: mass burials, Middle Ages, epidemic, famine, trauma, cranial surgery, trepanation

Received: 03.02.2021 Revised: 11.03.2021 Accepted: 19.03.2021

Citation: Brzobohatá H., Velímský F., Frolík J. 2021. Strong but not Unbeatable: Two Cases of Healed Severe Skull Trauma in Males Buried in Medieval Mass Graves (Kutná Hora-Sedlec, Czech Republic). "Fasciculi Archaeologiae Historicae” 34, 25-37, DOI 10.23858/ FAH34.2021.002

\section{Introduction}

During the Middle Ages, Kutná Hora was the second most important municipality after Prague in the Czech Kingdom. It was a centre for silver and copper mining, attracting workers from across the country and abroad. ${ }^{1}$ Yet while there is vast literature devoted to the technologies and organisation of mining at the site, ${ }^{2}$ little is known about the lives of those involved in the mining and processing of the silver ore. When silver

* Institute of Archaeology of the Czech Academy of Sciences, Prague, Czech Republic; (D https://orcid.org/0000-0002-46096402; brzobohata@arup.cas.cz

** Institute of Archaeology of the Czech Academy of Sciences, Prague, Czech Republic; (D https://orcid.org/0000-0003-06952064; velimsky@arup.cas.cz

*** Institute of Archaeology of the Czech Academy of Sciences, Prague, Czech Republic; (D https://orcid.org/0000-00021776-1311; frolik@arup.cas.cz

${ }^{1}$ Bartoš 2008.

${ }^{2}$ See the review in Bartoš 2008. mining reached its peak in the middle of the $14^{\text {th }}$ century, the town is thought to have numbered 18,000 inhabitants, with the specific features of a mining town inevitably reflected in its population development and social structure. ${ }^{3}$ The most numerous population group was probably workers employed in the mines, foundries, ore washing, coal depots, and transport. Both male and female workers were employed in washing and sorting ore. Other professions necessary for the function of the mines, foundries, metallurgy, and mints - such as prospectors, contractors, artisans, and merchants - and those providing a constant supply of food, wood, and brown coal also lived in this region. ${ }^{4}$ The inhabitants of Kutná Hora lived in a rapidly evolving and prospering agglomeration, yet had to face all the negative aspects of intensive urbanisation, such as severe overcrowding, poor sanitation, parasitic infestations, elevated risk of

\footnotetext{
${ }^{3}$ Molenda 1976; Frolík 2012.

${ }^{4}$ Molenda 1976.
} 


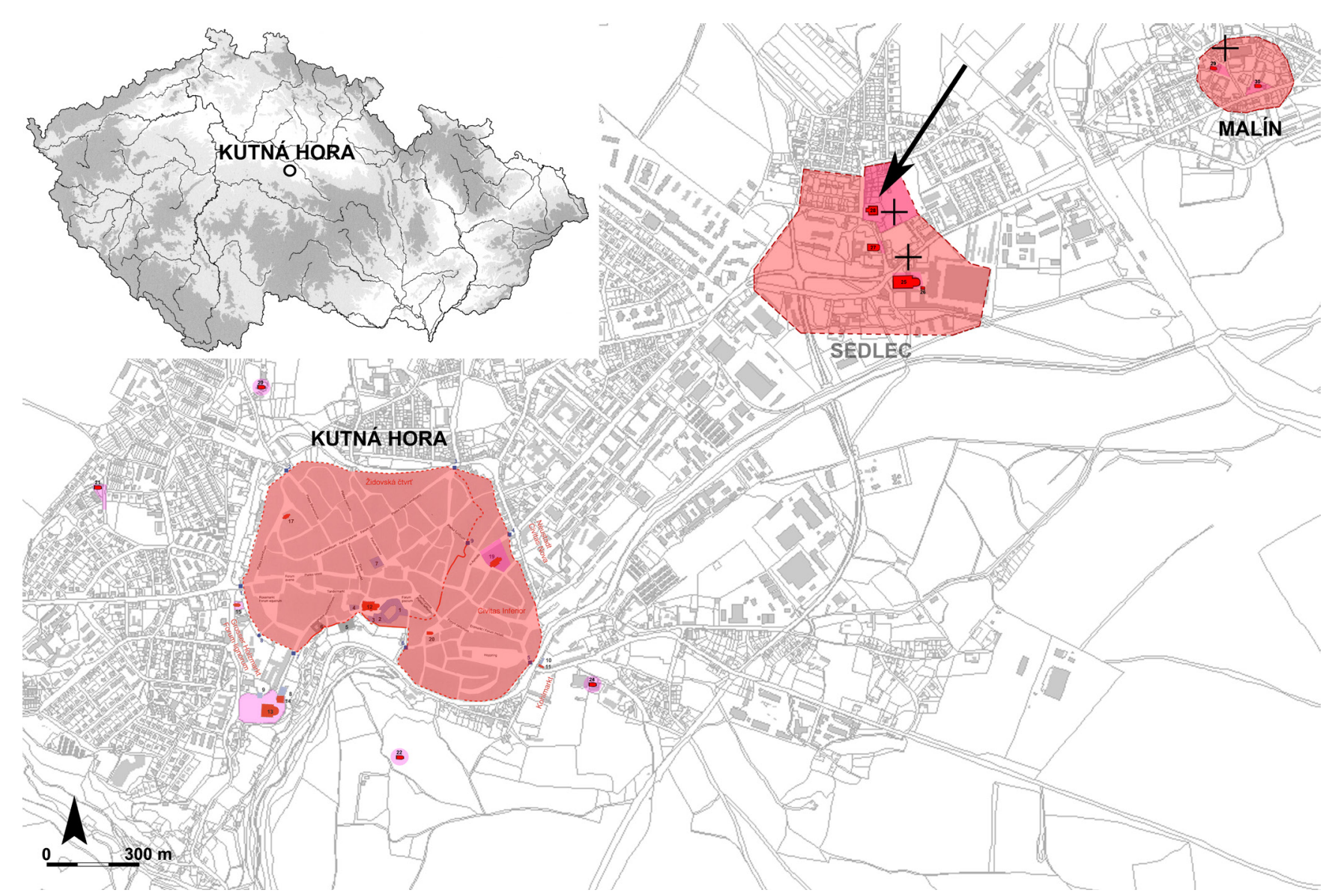

Fig. 1. Plan of today's Kutná Hora and its surroundings with markings to indicate the range of high medieval settlements at the turn of the $13^{\text {th }}$ and $14^{\text {th }}$ centuries (light red and bordered by dashed lines); high medieval church buildings (red ground plans); the location of the Kutná Hora-Sedlec Cemetery Church of All Saints with Ossuary (black arrow); and sites with the finds of the trepanned skulls mentioned in the text (black daggers).

infection, pollution, and dependency on food and wood supplies from the hinterland. ${ }^{5}$

Rescue archaeological research was carried out in 2016-2018 next to the Cemetery Church of All Saints with Ossuary in Kutná Hora-Sedlec to reinforce structural stability of the ossuary building. It revealed a vast medieval cemetery ${ }^{6}$ with a total of 1,845 skeletons unearthed. Most of them (more than half) were exhumed from mass burial pits. The taphonomy of the bones, the general lack of traumas ${ }^{7}$ among the mass grave skeletons and the demographic composition of the deceased clearly indicate synchronous deposition of the bodies and a change of burial rites due to epidemic and/ or famine. ${ }^{8}$ Preliminary archaeological research based on stratigraphic and numismatic methodological

\footnotetext{
${ }^{5}$ Moore et al. 2003.

${ }^{6}$ Frolík 2017a.

${ }^{7}$ E.g. crude prevalence of skull traumas (analysed to date) reaches $1 \%$.

${ }^{8}$ Castex 2008.
}

approaches, later verified by radiocarbon dating, links these mass graves to two catastrophic events occurring in the $14^{\text {th }}$ century. The first group of mass burials is attributed to the famine of 1318 following climate change and crop failures in the second decade of the $14^{\text {th }}$ century. ${ }^{9}$ It is assumed that the escalation in mortality was caused by a combination of starvation and infection rather than by hunger alone. ${ }^{10}$ The second group of mass burials is attributed to the plague epidemic in Europe from 1348-1350. The remaining graves (single inhumations) are archaeologically dated to the $13-14^{\text {th }}$ centuries and $14-16^{\text {th }}$ centuries, respectively. Considering the key environmental and epidemiological factors of medieval towns, nearly all microbial and viral transmission routes were facilitated by poor sanitation conditions, contaminated water, and overpopulation. For this reason, the exact cause of the establishment of such large-scale mass graveyards in a given

\footnotetext{
${ }^{9}$ Brázdil et al. 2018, 100 .

${ }^{10}$ Scrimshaw 1987.
} 

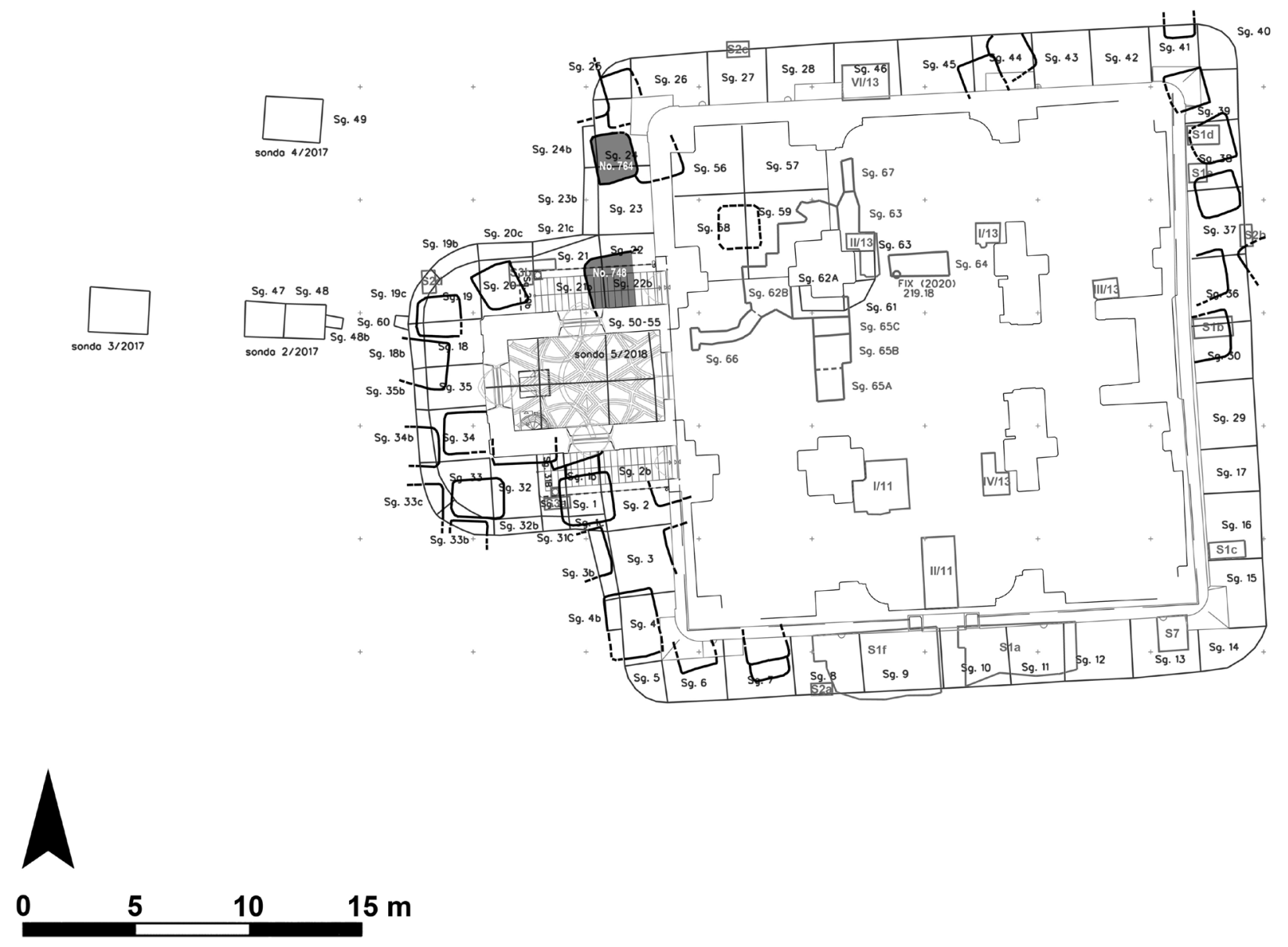

Fig. 2. Map showing the site area of the Kutná Hora-Sedlec Cemetery Church of All Saints with Ossuary and the location of mass grave no. 764 (sections 23-24) and no. 748 (section 22) (coloured in grey) within the excavated area.

site is yet to be verified (for example by using genetic methods to detect the pathogen DNA).

The field of archaeology has greatly benefited from studying epidemic graves, not only through gaining historical knowledge but also by furthering insight into palaeodemographic dynamics and by answering questions pertaining to palaeopathology. ${ }^{11}$ This is the case for the Kutná Hora-Sedlec findings with evidence of successful treatment of penetration of two skulls and the remarkable resilience of the treated males to recover. The male skeletons were discovered in mass grave no. 764 (individual no. 588) and no. 748 (individual no. 1556), respectively, both on the western side of the ossuary. We can merely speculate as to whether they had been treated in medieval Kutná Hora or whether they had come from somewhere else with these injuries. However, what is obvious and unquestionable is the resilience of these men to survive the skull trauma, despite not having sufficient strength to survive an encounter with a pathogen (most likely plague, individual no. 588) or famine or pathogen (individual no. 1556, found in a mass grave not yet assigned to a specific catastrophic event).

\section{Description of the site and materials}

Recorded evidence of prehistoric and medieval settlements in the Kutná Hora-Sedlec cadastre is abundant owing to long-term archaeological research of the site and its key subject, the famous Cistercian monastery. ${ }^{12}$ Although we know about the existence of a total of three large outdoor and four smaller indoor cemeteries within the monastery complex, it is assumed there may be others, including in the hinterland of the monastery. 


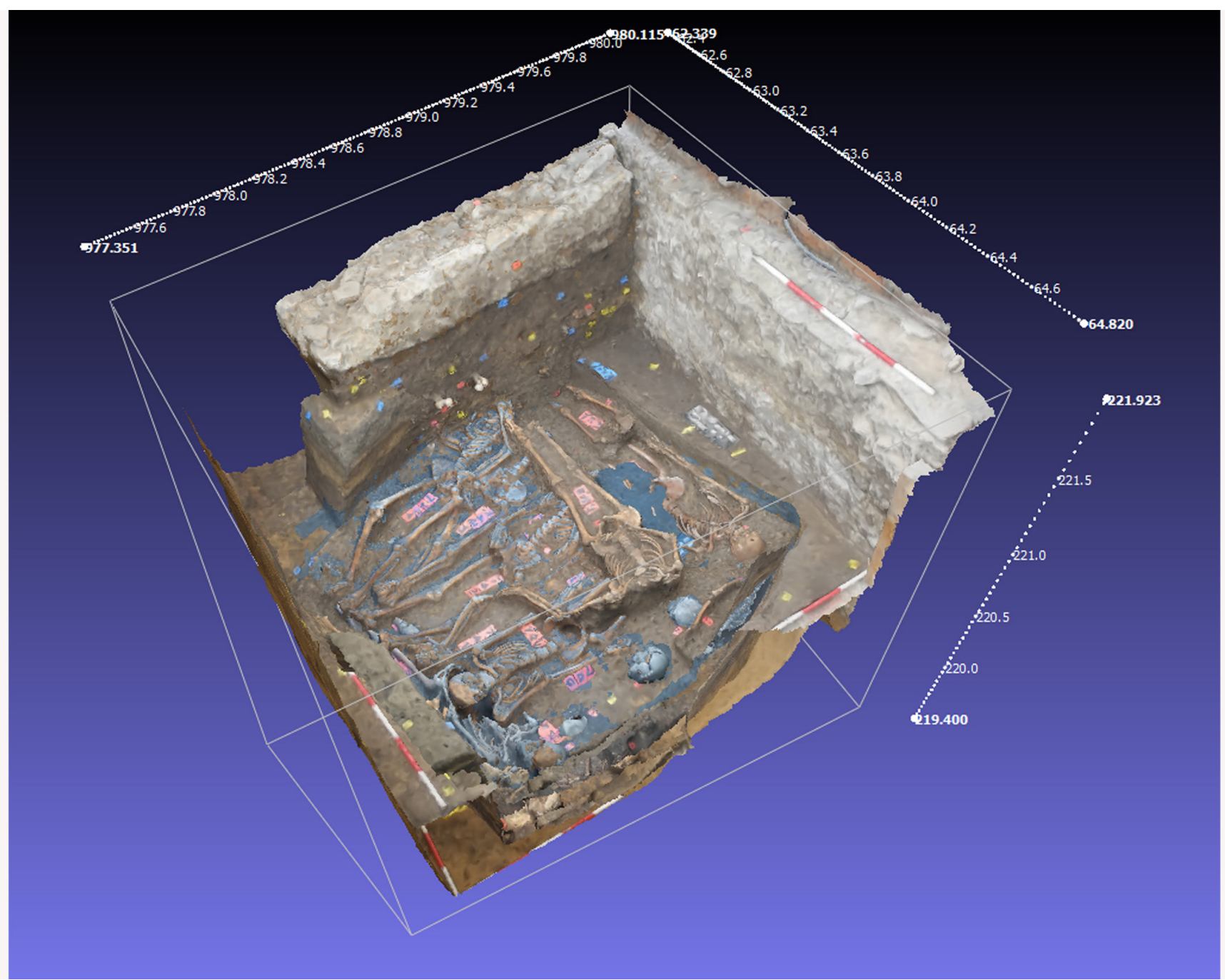

Fig. 3. 3D visualisation of mass grave no. 753 in section 20 in the Cemetery Church of All Saints with Ossuary, Kutná Hora-Sedlec, showing arrangement of simultaneously buried cadavers. Created by Geo.cz.

The Cemetery Church of All Saints with Ossuary, originally Gothic but later refurbished in the Baroque style in the $1700 \mathrm{~s}$, is located in the northern part of the monastery complex on a very gentle, north-rising slope forming part of the southern foot of Kaňk Hill (Fig. 1). The cemetery adjacent to the church building is still a functional burial ground for the local population, which is the reason why no archaeological research was carried out there until 2013. The cemetery has been documented in this position since the end of the $13^{\text {th }}$ century, when it was to be newly established as a lay cemetery for the monastery's subjects (tributaries) and the newly arrived population of upper settlements in the expanding town of Kutná Hora.

The first mention of Sedlec cemetery (Scedlicensi cimiterio) itself is in the Zbraslav Chronicle of Petr Žitavský, dating from before $1305 .{ }^{13}$ During further development, the cemetery repeatedly changed the area it occupied. The exact location of the boundary of the oldest cemetery complex is not known, but the cemetery certainly reached its maximum extent in the period before the outbreak of the Hussite wars, after which it gradually shrank to its current size, corresponding to approximately one sixth of the documented area of the late medieval cemetery.

The Cemetery Church of All Saints with Ossuary is estimated to contain the bones of 40,000-60,000 people arranged in patterns and pyramids. Recent rescue excavation in the graveyard surrounding the church with ossuary was necessitated by the planned reconstruction and stabilisation of this exceptional building. This led to the discovery of 32 complete and incomplete mass burials in its vicinity of more than 900 skeletons and slightly less individual graves, uniquely demonstrating large-scale mass mortality during well-defined periods ${ }^{14}$ (Fig. 2). 

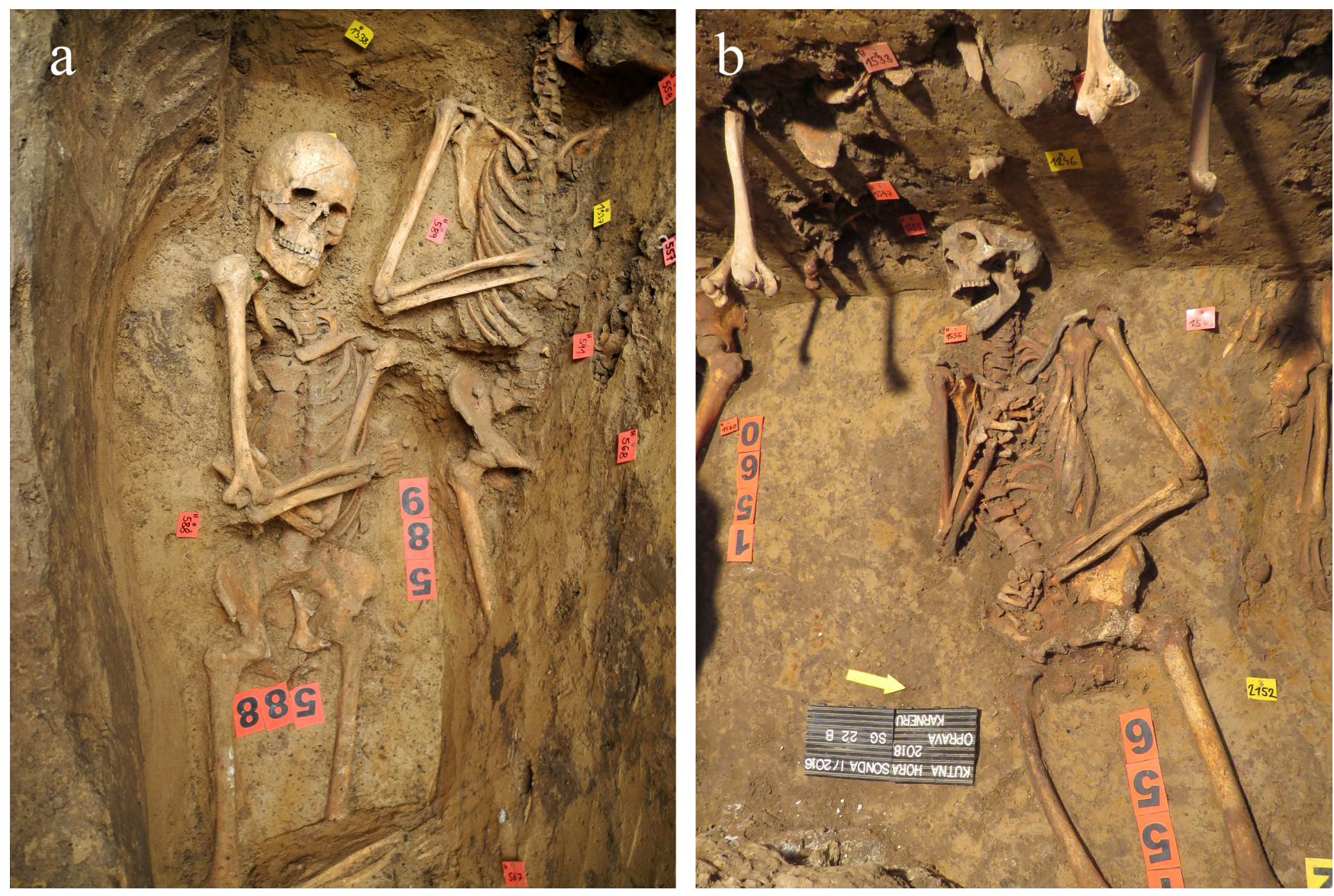

Fig. 4. Individual no. 588 (a) and individual no. 1556 (b) in situ.

The chronology of the mass graves at the ossuary is based on investigation of the stratigraphic configuration with two levels of pits corresponding to the two catastrophes. The younger stratigraphic level indicates damage by the ossuary walls. The younger graves are assigned to the victims of the 1348-1350 plague epidemic based on coin excavations from two graves (Prague groschen-type coins of the Czech King John of Luxembourg, reigned 1310-1346). These include the last mintings, dated 1346. Dates connected with later plague outbreaks are excluded because the ossuary was constructed prior to $1400 .{ }^{15}$ The older level is linked to the famine and burial of victims at the front of the gates of Sedlec in Kutná Hora based on the 1318 report of the Zbraslav Chronicle. ${ }^{16}$ Despite the catastrophic circumstances and large number of deceased, these mass graves exhibit the respectful and deliberate treatment of the dead. Coffinless corpses were laid out in a supine position within rectangular pits (c. $2 \times 2 \mathrm{~m}$, depth c. $2.5 \mathrm{~m}$ ) in several cross-stacked layers (Fig. 3), with child cadavers placed in the pit corners to economise use of the burial space.

\footnotetext{
${ }^{15}$ Poche 1980, 302; Chadraba 1984, 200.

${ }^{16}$ Zbraslavská kronika 1975, 317.
}

The disruption of the older, famine-related mass burials by the chronologically younger, Black Death-related ones suggests there were no markings on the earlier mass graves. This was similarly observed at construction of the chapel in the second half of the $14^{\text {th }}$ century, the foundations having being laid without apparent regard to the mass graves. The human skeletons under study, nos. 588 and 1556, were unearthed from mass grave no. 764 in sections 23 and 24, and from mass grave no. 748 in section 22 (Fig. 2), respectively, both in the usual position of their head facing west. The deceased no. 558 had his arms crossed on his chest, and the deceased no. 1556 had his right hand resting on his chest and his left hand on his belly (Fig. 4). The presence of the anatomic connections and the supine position of both skeletons indicate primary burials, the initial or direct inhumation of the fully articulated corpse, and the original position at interment. All skeletal remains from the site are deposited in an archive facility of the Archaeological Institute of the Czech Academy of Sciences in Kutná Hora and at the depository of the National Museum in Prague-Horní Počernice. 


\section{Methods}

Once cleaned and restored, the bones were analysed using traditional anthropological methods to determine sex, age at death, and body size. The age at death was estimated based on the degree of dental attrition and the metamorphosis of sternal rib ends and articular facets of the ilium. ${ }^{17}$ Sex was determined by the presence of masculine cranial and pelvic features. ${ }^{18}$ The length of the femur yielded estimated living stature ${ }^{19}$ which has been categorised according to the body height classes defined by Martin and Saller. ${ }^{20}$

All bones were examined macroscopically for pathological alterations. Evaluation of osseous lesions was primarily macroscopic. The trauma sites were examined under a 10x magnification hand lens to enable identification of the principal diagnostic features. To reveal the detailed three-dimensional (3D) appearance of the bones, the skullcaps were also subjected to optical scanning (smartSCAN 3D-HE, Breuckmann GmbH, Germany). The 3D geometric models of the skulls generated in the electronic STL format depict a 3D mesh of triangles in high resolution.

We evaluated the palaeopathological findings in accordance with the methodological criteria of Vyhnánek ${ }^{21}$ and Aufderheide and Rodríguez-Martín. ${ }^{22}$ Differential diagnosis with conditions likely to produce lesions in the skull was performed. We ruled out congenital and developmental defects, pathological lesions due to disease (such as infection or malignancy), and pseudopathologic post-mortem defects. In order to assess the origin of the wound and to check if the individual survived the traumatic event (even shortly) the exact dry bone appearance and differential healing indicators are of decisive importance. For this purpose, we adopted the diagnostic criteria presented by Kaufman, ${ }^{23}$ Boylston, ${ }^{24}$ Lovell, ${ }^{25}$ and Kushner. ${ }^{26}$

\section{Results}

Skeleton no. 588 was found in a stretched supine position with both arms bent at the elbows and resting on the chest (Fig. 4). The skeletal remains belonged to a robust, moderately-muscled man whose maximum lengths of the long limb bones (Table 1) yielded an estimated living stature of approximately $162.0 \mathrm{~cm}$.

\footnotetext{
${ }_{17}$ Todd 1920; Iscan et al. 1984; Lovejoy 1985; Schmitt 2005.

${ }^{18}$ Phenice 1969; Ferembach et al. 1980; Brůžek 2002.

${ }^{19}$ Sjovold 1990; Pearson 1898.

${ }^{20}$ Martin and Saller 1957, 324.

${ }^{21}$ Vyhnánek 1999, 386.

${ }^{22}$ Aufderheide and Rodríguez-Martín 2011, 31-34.

${ }^{23}$ Kaufman et al. 1997.

${ }^{24}$ Boylston 2000.

${ }^{25}$ Lovell 2008.

${ }^{26}$ Kushner et al. 2018.
}

The age at death was estimated to be between 20 and 30 years based on the metamorphosis of the articular facets of the ilium and sternal ends of the ribs. The sex was determined by the presence of well-defined, characteristic masculine cranial and pelvic features. His dental traits comprised only slight maxillary and mandibular dental wear, two caries, ante mortem tooth loss of the lower right M2, and moderate deposits of dental calculus. Pathological conditions included subtle healed cribra orbitalia observed in the roofs of both eye sockets, periapical lesion and dentoalveolar fistula of the upper right I1, bone remodelling after inflammatory process of the periosteum in both tibial shafts, and a healed skull injury or trepanation.

The injury and/or surgical intervention left an ovoid penetrating defect measuring $31 \times 20 \mathrm{~mm}^{27}$ $(57 \times 29 \mathrm{~mm}$ when including the whole depression on the outer table) with smooth margins, located in the middle of the right parietal bone. The longer axis of the roughly oval shape is perpendicular to the sagittal suture. Medial and anterior margins are slightly sloping, while posterior and lateral edges are somewhat steeper (Fig. 5). While the outer bony surface is without signs of inflammatory complications, the inner plate reveals numerous imprints of small vessels in the vicinity of the defect. The appearance of the edges does not indicate a simple tangential section of the calva as it might seem at first glance. More likely, it could have been an incision caused by a forceful blow to the head using a sharp-edged weapon from above and anterior, from which the partially shaved part of the bone could have subsequently been removed during the clearing of the wound and curative procedures. On the other hand, it cannot be ruled out that this was a case of trepanation in sensu stricto, performed e.g. by scraping with a sharp instrument, not associated with any previous injury.

Human skeleton no. 1556 belonged to an adult male, with a robust body construction and moderatelydeveloped muscular insertions. The stature of the individual was estimated to be $163 \mathrm{~cm}$, and the age at death was estimated to be between 30 and 50 years based on the metamorphosis of the articular facets of the ilium and sternal ends of the ribs. The sex was determined by the presence of well-defined, characteristic masculine cranial and pelvic features. His dental traits comprised moderate to severe dental attrition, ante mortem tooth loss of the upper right M2, and moderate deposits of dental calculus. Pathological conditions included healed fractures of five ribs, a small (probably posttraumatic) myositis ossificans lesion in the right

\footnotetext{
${ }^{27}$ Diameters of the opening, measured on the inner table.
} 
Table 1. Basic information about analysed individuals/skull traumas.

\begin{tabular}{|c|c|c|}
\hline Characteristics & Individual no. 588 & Individual no. 1556 \\
\hline Sex; age (years) & Male; $20-30$ & Male; 30-50 \\
\hline $\begin{array}{l}\text { Stature (Pearson 1898) }(\mathrm{cm}) \text { and stature } \\
\text { category (Martin and Saller 1957) }\end{array}$ & 162.15 (below medium) & 162.90 (below medium) \\
\hline Stature (Sjovold 1990) (cm) & $163.05 \pm 4.52$ & $164.2 \pm 4.52$ \\
\hline Dental traits & $\begin{array}{l}\text { Two caries, ante mortem tooth loss of } \\
\text { the lower right M2, periapical lesion and } \\
\text { dentoalveolar fistula of the upper right I1 }\end{array}$ & $\begin{array}{l}\text { Ante mortem tooth loss of the upper } \\
\text { right M2 }\end{array}$ \\
\hline Pathology & $\begin{array}{l}\text { Cribra orbitalia, periostitis tibiae and } \\
\text { healed skull injury or trepanation }\end{array}$ & $\begin{array}{l}\text { Healed fractures of five ribs, myositis } \\
\text { ossificans lesion in the right humerus, } \\
\text { healed skull injury }\end{array}$ \\
\hline Size of skull defect (mm) & $31 \times 20$ & $56 \times 45$ \\
\hline Surgical technique employed & Scraping? & Sawing \\
\hline Probable cause of intervention & $\begin{array}{l}\text { Unknown, probably therapeutic } \\
\text { due to trauma }\end{array}$ & $\begin{array}{l}\text { Therapeutic, due to extensive sharp } \\
\text { force trauma }\end{array}$ \\
\hline State of healing & Fully healed & Fully healed \\
\hline Survival & Long-term & Long-term \\
\hline \multicolumn{3}{|l|}{ Cranial measurements (mm) } \\
\hline Maximum cranial length & Not measurable & 174 \\
\hline Maximum cranial breadth & Not measurable & 142 \\
\hline Basion-bregma height & Not measurable & 128 \\
\hline Minimum frontal breadth & Not measurable & 96 \\
\hline \multicolumn{3}{|c|}{ Long bones measurements (mm) (right side) } \\
\hline Maximum humeral length & 340 & 328 \\
\hline Maximum radial length & Not measurable & 235 \\
\hline Maximum ulnar length & 262 & 259 \\
\hline Maximum femoral length & 430 & 434 \\
\hline Tibial medial length & 358 & Not measurable \\
\hline
\end{tabular}

humerus, and a healed skull injury. The character of these injuries suggests their possible co-occurrence during a single violent event.

Visual examination of the cranial vault revealed a semi-ovoid incision (measuring $56 \times 45 \mathrm{~mm}$ ) in the left parietal bone, elongated in shape, with the longer axis of the defect running parallel to the sagittal suture (Fig. 6). The margins of the penetrating injury are mostly sloping and modified by extensive healing. The overall appearance of this linearly cut and well-defined injury meets the diagnostic criteria of sharp force trauma. ${ }^{28}$ However, its initial appearance was significantly altered not only by the healing process itself but also by surgical intervention. Part of the bone partially split off during the trauma remained slightly elevated due to the healing process and subsequent medical treatment. The appearance of the edge where the slender D-shaped part is missing suggests that a small part of this bone flap was surgically removed, most likely to facilitate access to the deeper parts and cleaning of the wound. At the exact line of the removal, the edge profiles of the wound are perpendicular and smooth, suggesting the use of a saw-like metal instrument and healing as the remaining wound margins. There are no traces of pitting, porosity, or inflammation around the defect, although the inner plate of the cranial bones cannot be assessed. The overall appearance, location, parameters, and profile of the trauma suggest a sharp force impact or a blow dealt from above and behind by a right-handed attacker armed with a sword or axe.

${ }^{28}$ Boylston 2000. 

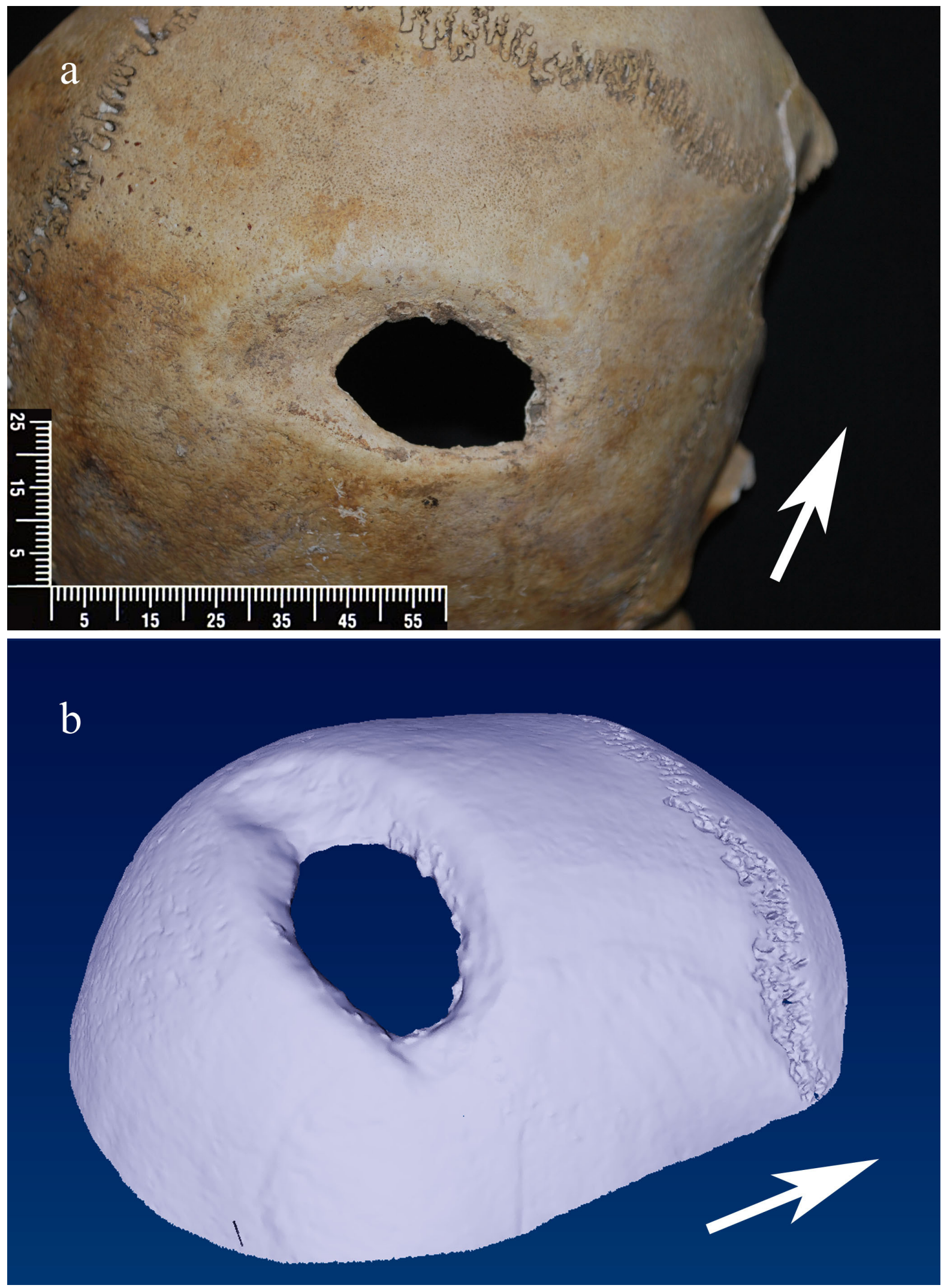

Fig. 5. Right superior view of the right parietal bone of individual no. 588 with oval hole (a). On closer examination, using a 3D digitised outer aspect of the same bone, we can observe the morphology of the margins of the wound (b). Arrows point to the front of the skull. 

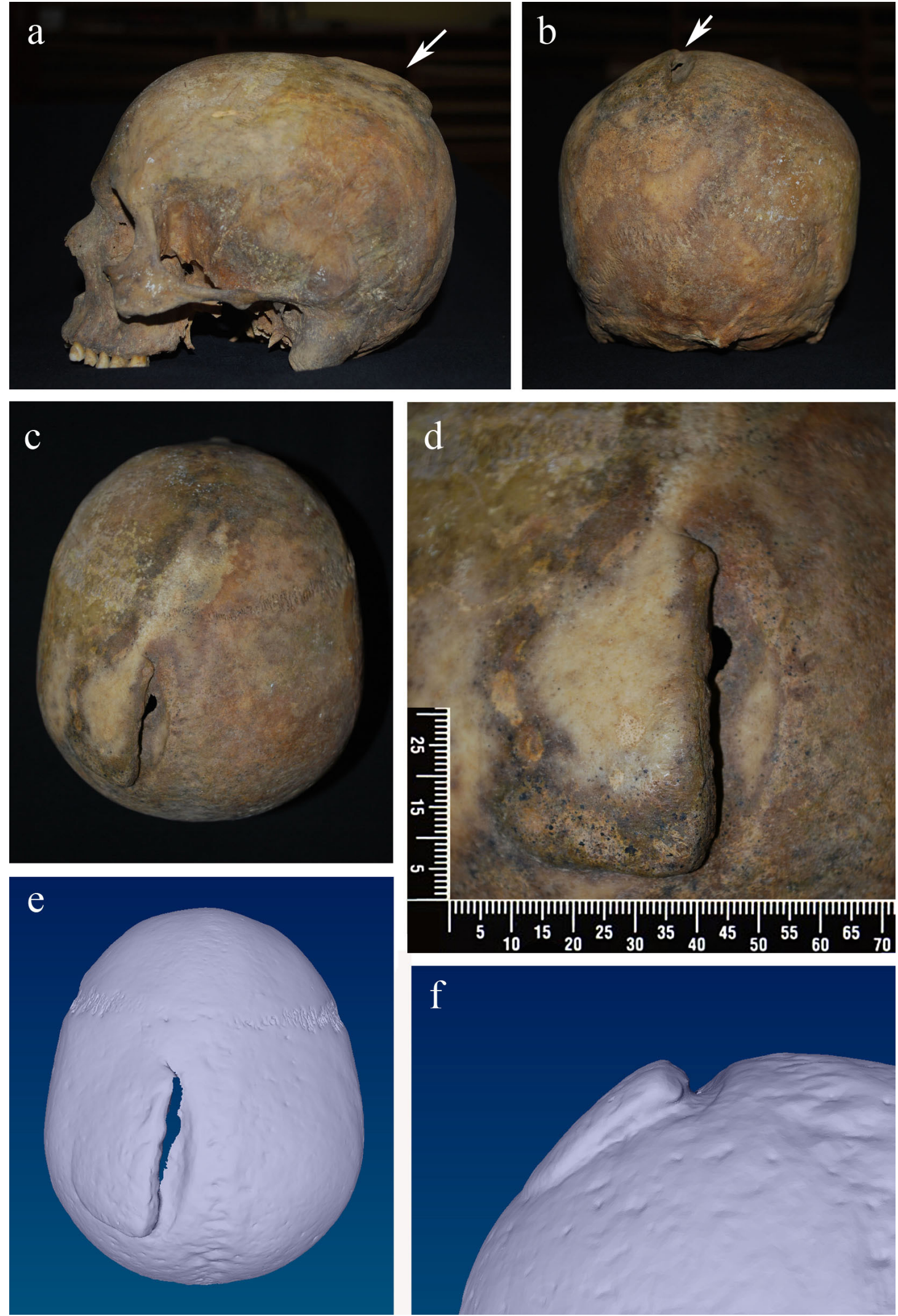

Fig. 6. Left lateral (a), posterior (b), and superior (c) view of the skull of skeleton no. 1556 with the semi-ovoid healed incision in the left parietal bone (indicated by an arrow

in lateral and posterior views). Detail of the wound (d) with a clearly visible missing flake of bone, and superior (e) and posterior (f) view of the 3D cranial model. 


\section{Discussion}

The human skeleton is an invaluable source of data about an individual's life history and the living conditions of past societies. The study of human skeletal remains from historic and prehistoric mass burials is a research field of high intensity. Previously published mass grave studies suggest that these findings are far more than just evidence of abnormal mortality. The sudden increase in mortality and the need for the rapid disposal of very large numbers of cadavers substantially eliminates the possibility of dividing victims, for example, by social status, sex, age, or religion. For this reason, the resulting group of deceased often accurately reflects the composition of a population affected by a catastrophe. ${ }^{29}$

As for written records on non-conflict-related burial pits in Czech territory, there is historical and written evidence for the digging of mass graves during the famines of $1282^{30}$ and $1318,{ }^{31}$ with precise descriptions of their locations. The reports of plague flare-ups from 1348-1350 are written about more generally, ${ }^{32}$ as are reports of later epidemics. However, the actual number of uncovered and well-documented mass graves is not very high. The discoveries of epidemic- and famine-related graves from medieval and early modern Czech sites are summarised in Brzobohatá et al., ${ }^{33}$ where we also presented the largest set of medieval mass graves in the Czech Republic recently excavated in Kutná Hora-Sedlec. The mass synchronous deposition of cadavers in Kutná Hora-Sedlec offers vast bioarchaeological data with temporal and spatial restriction to Czech medieval mortality crises. Pilot analyses show that individuals recovered from these mass graves represent all age groups and both sexes. In the preliminary results of ongoing analyses we can see only one deviation in the data: adult males outnumber females (probably owing to labour migration and intensive silver mining at the given site and time) - so far 386 males and 233 females have been identified, with a male to female ratio close to 1.7.

Two men buried in the mass graves show signs of extensive healing of the skull, and therefore must have survived for at least several months (or possibly years) after suffering from penetrating skull trauma prior to their deaths by famine or plague. Modern case studies provide evidence that trepanation defects do not show osseous healing until 70 days post defect. This healing process is characterised by a smoothing of the trepanation margins and a loss of the typical layering

\footnotetext{
${ }^{29}$ Alfani and Murphy 2017.

${ }^{30}$ Pokračovatelé Kosmovi, 179-180.

31 Zbraslavská kronika, 317.

${ }^{32}$ Kroniky doby Karla IV, 156, 226, 228.

${ }^{33}$ Brzobohatá et al. 2019.
}

of the skull bone, that is, internal and external tabula with diploe. ${ }^{34}$ Weapon-related trauma is the most apparent evidence of interpersonal violence, which was an integral aspect of medieval life. ${ }^{35}$ Research of weapon-related traumas linked to individual or group deaths in medieval times shows the full spectrum of society from king to commoner was affected. ${ }^{36}$ In most cases of violent attack, the head was probably the principal target of the aggressors. Considering injury distribution by skeletal elements, data show that the parietals are the most commonly affected cranial bones, as they comprise the largest proportion of the skull vault. ${ }^{37}$ If a right-handed adversary were facing the victim, most injuries caused by them would be to the left side of the victim's body. Thus, a traumatic lesion situated on the left parietal is probably indicative of face-to-face combat in which the individuals who struck the blows were right handed. ${ }^{38}$ This was probably the case with Sedlec male no. 1556, with the difference being that he must have been attacked from above and behind (such as an attack from a mounted antagonist, or an attack by an aggressor standing over someone lying on the ground).

There is other evidence of posttraumatic cranial surgery from the medieval period in the region under study. A remarkable example of posttraumatic trepanation was found during rescue excavation in adjacent Malín (about $1 \mathrm{~km}$ distant from Kutná HoraSedlec) in $2003 .{ }^{39}$ The pathological conditions of skeleton no. 10622 , dating to the first half of $13^{\text {th }}$ century and belonging to a young male aged 18 to 20 years, included one healed (parasagittal and professionally treated) and two unhealed incisions on the left parietal bone.

Another find of a trepanned skull in Kutná HoraSedlec comes from the rescue research conducted by F. Velímský. Behind the presbytery of the Cathedral of the Assumption of Our Lady, a section of a multiple-stage medieval cemetery of 295 graves in total was discovered in 2007. The skull in question was unearthed from grave no. 41, together with other skeletal remains of an adult man aged 35-50 years. In the frontal bone, on the median line and $20 \mathrm{~mm}$ in the front of the bregma point, there was a small round opening, $8 \mathrm{~mm}$ in diameter. The edges were perfectly healed. Moreover, the outer surface of the frontal bone was slightly lowered around the bone hole in the form of a round depression of $15 \mathrm{~mm}$ in diameter. This surgery was performed by a drilling method using a trepan used in the post-medieval

\footnotetext{
${ }^{34}$ Arnott et al. 2003, 43.

${ }^{35}$ Kaeuper 2000, 13.

${ }^{36}$ Krakowka 2017.

${ }^{37}$ Fibiger et al. 2013.

${ }^{38}$ Murphy 2003, 212.

${ }^{39}$ Velímský et al. 2007.
} 
era with a so-called protective board, which protected the tool from penetrating too deeply into the bone. Radiocarbon dating has confirmed that the skull dates to the $12^{\text {th }}-13^{\text {th }}$ centuries, making this find unique. The cranium shows no pathological changes that could be the reason for such an operation. Thus, the motive behind the operation is not known but could have been a treatment for migraines, epilepsy, or psychological disorders. ${ }^{40}$

Of all the forms of surgical intervention for whatever reason, that of making holes in the skull is possibly the oldest. ${ }^{41}$ Widespread in many cultures, it is one of the earliest forms of intervention involving a bony structure whose evidence forms part of the archaeological record. ${ }^{42}$ A summary of prehistoric and historic trepanned skulls found in the Czech territory includes 51 items involving twelve from the Middle Ages. ${ }^{43} \mathrm{An}$ other eight trepanned skulls including six medieval crania were reported by Likovský and co-authors. ${ }^{44}$ The operation would have required a good deal of stoicism on the part of the patient since it would have involved cutting and exposing the scalp from the underlying bone, achieved by the shedding of much blood (given the vascularity of the scalp) and removal of bone, all without modern medical equipment, modern forms of anaesthesia, antibiotics, or painkillers. ${ }^{45}$ Medieval reports regrettably lack much of the modern documentation of surgical indications, procedures, and patient outcomes. ${ }^{46}$ How the Kutná Hora-Sedlec individuals were anaesthetised (such as by narcotic drugs or plant extracts), if at all, is not known. What is certain, however, is that these procedures were not carried out under aseptic conditions.

\section{Conclusion}

In conclusion, the exceptional skeletal assemblage from Kutná Hora-Sedlec, although not yet completely processed and analysed, has already offered researchers the opportunity to examine the skeletal remains of two males who survived severe head injury and then succumbed to an epidemic (individual no. 588) or to a famine or an epidemic (individual no. 1556). Both cases reveal a system of medical knowledge and treatment attained by practitioners and/or barbers in the medieval era. In addition to the evidence of healing, in at least one case we could demonstrate the use of a surgical instrument and partial removal of a bone flap. Our observations thus provide valuable data on the level of medical treatment and general management of head wounds in the $14^{\text {th }}$ century.

\section{Acknowledgements}

This project was funded by the Grant Agency of the Czech Republic (Project no. 21-09637S).

\section{Sources}

FRB IV - Zbraslavská kronika: Petra Žitavského Kronika zbraslavská (Chronicon Aulae Regiae). Fontes rerum Bohemicarum IV, Pragae 1884.

Kroniky doby Karla IV - Kroniky doby Karla IV. Prague 1987.

Pokračovatelé Kosmovi - Pokračovatelé Kosmovi. Prague 1974.

Zbraslavská kronika - Zbraslavská kronika - Chronicon Aulae Regiae. Prague 1975.

\section{References}

Alfani G., Murphy T. E. 2017. Plague and Lethal Epidemics in the Pre-Industrial World. "Journal of Economic History" 77(1), 314-343.

\footnotetext{
${ }^{40}$ Velímský et al. 2008; Likovský et al. 2010.

${ }^{41}$ Rocca 2003, 254; Buchfelder 2005.

${ }^{42}$ Arnott et al. 2003, 43; Bennike 2003, 95; Redfern and Roberts 2019, 268.

${ }^{43}$ Malyková 2002.

${ }^{44}$ Likovský et al. 2010.

${ }^{45}$ Waldron 2009, 161.
}

${ }^{46}$ Buchfelder 2005; González Darder 2019, 101. 
Arnott R., Finger S., Smith C. (eds.) 2003. Trepanation. History, Discovery, Theory. Lisse.

Aufderheide A. C., Rodríguez-Martín C. (eds.) 2011. The Cambridge Encyclopedia of Human Paleopathology. Cambridge.

Bartoš M. 2008. Středověké dobývání v Kutné Hoře. In: Přispěvky k dějinám dolování stříbra 2. Kutnohorsko Vlastivědný Sborník 9/08, 1-44.

Beauchamp A. M. 2012. The Black Death, Plague, and Mass Mortality. "Journal of the University of Manitoba Anthropology Students' Association" 30, 1-16.

Bennike P. 2003. Ancient Trepanations and Differential Diagnosis: A Re-Evaluation of Skeletal Remains from Denmark. In: R. Arnott, S. Finger, C. Smith (eds.), Trepanation, History, Discovery, Theory. Lisse, 95-116.

Boylston A. 2000. Evidence for Weapon Related Trauma in British Archaeological Samples. In: M. Cox, S. Mays (eds.), Human Osteology in Archaeology and Forensic Science. London, 357-380.

Brázdil R., Kotyza O., Bauch M. 2018. Climate and Famines in the Czech Lands Prior to AD 1500: Possible Interconnections in a European Context. In: D. Collet, M. Schuh (eds.) Famines during the "Little Ice Age" (1300-1800). Cham, 91-114.

Brůžek J. 2002. A Method for Visual Determination of Sex, Using the Human Hip Bone. "American Journal of Physical Anthropology" 117(2), 157-168.

Brzobohatá H., Frolík J., Zazvonilová E. 2019. Bioarchaeology of Past Epidemic- and Famine-Related Mass Burials with Respect to Recent findings from the Czech Republic. "Interdisciplinaria Archaeologica. Natural Sciences in Archaeology" 10(1), 79-87.

Buchfelder M. 2005. From Trephination to Tailored Resection: Neurosurgery in Germany before World War II. "Neurosurgery" 56(3), 605-613.

Castex D. 2008. Identification and Interpretation of Historical Cemeteries Linked to Epidemics. In: D. Raoult, M. Drancourt (eds.), Paleomicrobiology: Past Human Infections. Berlin, Heidelberg, 23-48.

Chadraba R. 1984. Dějiny českého výtvarného uměni I/1. Od počátků do konce středověku. Praha.

Charvátová K. 2013. Dějiny cisterckého řádu v Čechách 1142-1420. 1. svazek, Fundace 12. století. Praha.

Ferembach D., Schwidetzky I., Stloukal M. 1980. Recommendations for Age and Sex Diagnosis of Skeletons. "Journal of Human Evolution" 9, 517-549.

Fibiger L., Ahlström T., Bennike P., Schulting R. J. 2013. Patterns of violence-related skull trauma in Neolithic Southern Scandinavia. "American Journal of Physical Anthropology” 150(2), 190-202.

Frolík J. 2012. Archaeological Examination of Medieval Towns in Bohemia (An Overview by an Archaeologist). "Analecta Archaeologica Ressoviensia" 7: Archaeology in a Town, a Town in Archaeology, 67-109.

Frolík J. 2017a. Pohřbivání ve vrcholném středověku a v novověku na Chrudimsku, Pardubicku a Kolínsku Bestattungen im Hochmittelalter und in der Neuzeit in den Regionen Chrudim, Pardubice und Kolín. "Archaeologia Historica" 42(1), 187-205.

Frolík J. 2017b. Záchranný archeologický výzkum při odvodněni hřbitovniho kostela Všech svatých s kostnici $v$ Kutné Hoře-Sedlci - Archäologische Retunggrabung bei der Entwässerung des Beinhauses in Kutná Hora-Sedlec. "Zprávy ČAS - Supplément" 105, 34-35

Frolík J. 2018. Pokračování záchranného archeologického výzkumu u hřbitovního kostela Všech Svatých s kostnici $v$ Kutné Hoře-Sedlci - Forsetzung der archäologischen Rettungsgrabung bei der Kirchhof-Allerheiligenkirche mit dem Beinhaus in Kutná Hora/Kuttenberg-Sedlec. "Zprávy ČAS - Supplément" 109, 35-36.

González Darder J. M. 2019. Cranial Trepanation during the Middle Ages. In: Trepanation, Trephining and Craniotomy. History and Stories. Cham, 95-107.

Işcan M. Y., Loth S. R., Wright R. K. 1984. Metamorphosis at the sternal rib end: a new method to estimate age at death in white males. "American Journal of Physical Anthropology" 65(2), 147-156.

Kaeuper R.W. 2000. Violence in Medieval Society. Woodbridge.

Kaufman M. H., Whitaker D., McTavish J. 1997. Differential Diagnosis of Holes in the Calvarium: Application of Modern Clinical Data to Paleopathology. "Journal of Archaeological Science" 24(3), 193-218.

Krakowka K. 2017. Patterns and Prevalence of Violence-Related Skull Trauma in Medieval London. "American Journal of Physical Anthropology" 164(3), 488-504.

Kushner D. S., Verano J. W., Titelbaum A. R. 2018. Trepanation Procedures/Outcomes: Comparison of Prehistoric Peru with Other Ancient, Medieval, and American Civil War Cranial Surgery. "World Neurosurgery" 114, 245-251.

Likovský J., Malyková D., Brzobohatá H., Stránská P. 2010. Causations and Methods of the Skull Trepanation in the Past from the Point of View of the Latest Findings from the Czech Territory. "Anthropologie" 48(1), 19-32. 
Lovejoy C. O. 1985. Dental Wear in the Libben Population: Its Functional Pattern and Role in the Determination of Adult Skeletal Age at Death. "American Journal of Physical Anthropology" 68(1), 47-56.

Lovell N. C. 2008. Analysis and Interpretation of Skeletal Trauma. In: M. A. Katzenberg, S. R. Saunders (eds.), Biological Anthropology of the Human Skeleton (2nd edition). Hoboken, 341-386.

Malyková D. 2002. Trepanace lebky v archeologických nálezech z území Čech / Trephinated Skulls among Archaeological Finds from Bohemia. "Archeologie ve středních Čechách" 6(1), 293-314.

Martin R., Saller K. 1957. Lehrbuch der Anthropologie in systematischer Darstellung mit besonderer Berücksichtigung der anthropologischen Methoden 1 ( $3^{\text {rd }}$ edition). Stuttgart.

Molenda D. 1976. Mining Towns in Central-Eastern Europe in Feudal Times. Problem Outline. "Acta Poloniae Historica" 34, 165-188.

Moore M., Gould P., Keary B. S. 2003. Global Urbanization and Impact on Health. "International Journal of Hygiene and Environmental Health" 206(4-5), 269-278.

Murphy E. M. 2003. Trepanations and Perforated Crania from Iron Age South Siberia: An Exercise in Differential Diagnosis. In: R. Arnott, S. Finger, C. Smith (eds.), Trepanation, History, Discovery, Theory. Lisse, 209-221.

Pearson K. 1899. Mathematical Contributions to the Theory of Evolution. - V. On the Reconstruction of the Stature of Prehistoric Races. "Philosophical Transactions of the Royal Society of London" 192, 169-244.

Phenice T. W. 1969. A Newly Developed Visual Method of Sexing the Os Pubis. "American Journal of Physical Anthropology" 30(2), 297-301.

Poche E. 1980. Umělecké památky Čech 3. Prague.

Redfern R., Roberts C. A. 2019. Trauma. In: J. Buikstra (ed.), Ortner's Identification of Pathological Conditions in Human Skeletal Remains (3 ${ }^{\text {rd }}$ edition). San Diego, 211-284.

Rocca J. 2003. Galen and the uses of trepanation. In: R. Arnott, S. Finger, C. Smith (eds.), Trepanation, History, Discovery, Theory. Lisse, 253-271.

Schmitt A. 2005. Une nouvelle méthode pour estimer l'âge au décès des adultes à partir de la surface sacropelvienne iliaque / A new method to assess adult age at death from the iliac sacro-pelvic surface. "Bulletins et Mémoires de la Société d'Anthropológie de Paris" 17(1-2), 89-101.

Scrimshaw N. S. 1987. The phenomenon of famine. "Annual Review of Nutrition" 7, 1-21.

Sjovold T. 1990. Estimation of stature from long bones utilizing the line of organic correlation. "Human Evolution" 5, 431-447.

Todd T. W. 1920. Age Changes in Pubic Bone. I. The Male White Pubis. "American Journal of Physical Anthropology" 3(3), 285-334.

Vyhnánek L. 1999. Nárys kosterní paleopatologie se zaměřením na radiodiagnostiku. In: M. Stloukal (ed.), Antropologie: príručka pro studium kostry. Prague, 386-432.

Velímský F. 2009. Přehled výsledků dosavadního archeologického pri̊zkumu areálu cisterciáckého kláštera v Sedlci u Kutné Hory. In: R. Lomičková (ed.), Sedlec. Historie, architektura a umělecká tvorba sedleckého kláštera ve středoevropském kontextu kolem roku 1300 a 1700 / Sedletz. Geschichte, Architektur und Kunstschaffen im Sedletzer Kloster im mitteleuropäischen Kontext um die Jahre 1300 und 1700. Opera Facultatis Theologiae catholicae Universitatis Carolinae Pragensis. Historia et historia artium 10. Praha, 385-398.

Velímský F., Hošek J., Stránská P. 2007. Quod me nutrit me destruit. In: W. Dzieduszycki, J. Wrzesiński (eds.), Środowisko pośmiertne czlowieka. Funeralia Lednickie. Spotkanie 9. Poznań, 389-402.

Velímský F., Pospíšil A., Brzobohatá H., Štaffen Z. 2008. Př́spěvek k poznáni stavby kostela Nanebevzetí Panny Marie v Sedlci u Kutné Hory. "Průzkumy památek" 14, 57-70.

Waldron T. 2009. Paleopathology. Cambrigde manuals in archaeology. New York. 
